\title{
Gerakan sosial Nahdlatul Ulama: Studi kasus Pengurus Cabang Nahdlatul Ulama Kota Malang
}

\section{Muhammad Luthfil Hakim}

Universitas Brawijaya, Indonesia

\begin{abstract}
INTISARI
Penelitian ini berupaya untuk menjelaskan mengenai gerakan sosial PCNU Kota Malang pada tahun 2010-2015 dengan menggunakan metode kualitatif deskriptif. Penelitian ini menggunakan teori gerakan sosial karya Mc Adam, Mc Charty dan Zald. Hasil penelitian menunjukkan bahwa gerakan sosial Nahdlatul Ulama' (NU) pada masa reformasi memiliki pola yang berbeda dengan masa sebelumnya. Pada masa reformasi, strategi gerakan NU mengedepankan tiga cara yakni melalui program struktural, dakwah, dan mediasi. Dengan melakukan studi kasus di PCNU Kota Malang penelitian ini menemukan bahwa gerakan NU di era reformasi muncul dan dapat eksis akibat adanya keterbukaan struktur sosial dan ketidakseimbangan politik di Kota Malang. Proses tersebut kemudian juga dikuatkan oleh kekuatan aktor perubahan PCNU Kota Malang yang meliputi: ulama' (kyai), aktivis, politisi dan akademisi.
\end{abstract}

\section{KATA KUNCI}

Gerakan Sosial; Nahdlatul Ulama, PCNU Kota Malang

\section{Pendahuluan}

$\mathrm{P}$ CNU (Pengurus Cabang Nahdlatul Ulama') Kota Malang merupakan bagian dari struktur organisasi formal NU (Nahdlatul Ulama') yang mengaktualisasikan tujuan organisasi di tingkat kabupaten/kota. Dikatakan sebagai organisasi gerakan sosial dikarenakan PCNU Kota Malang merupakan perilaku kelompok antar individu secara kolektif yang memiliki tujuan dalam melakukan interaksi terhadap pemerintah atau lawan. ${ }^{1}$ Sejak Muktamar NU di tahun 1984, NU berkembang menjadi organisasi sosial keagamaan yang secara resmi keluar dari kegiatan politik praktis. NU sebagai organisasi sosial keagamaan memiliki tujuan yang mengedepankan pada kemaslahatan masyarakat, kemajuan bangsa, dan ketinggian harkat dan martabat manusia (Anggaran Dasar Nahdlatul Ulama Tahun 2010).

\section{Korespodensi:}

Pascasarjana Fakultas IImu Administrasi, Universitas Brawijaya, Jln. Mayjend Haryono No. 163 Malang 65145 Email: luthfil@nalarkritis.org 
Secara kelembagaan politik, pada awalnya NU merupakan organisasi sosial keagamaan yang lahir pada 31 Januari 1926 M di Surabaya. ${ }^{2}$ Selanjutnya, NU pernah menjadi bagian dari Partai Masyumi pada tahun 1945, namun keluar kembali sebagai organisasi yang tidak dalam wilayah politik praktis pada tahun 1952 melalui Muktamar XIX. Keluarnya NU dari Masyumi lebih dikarenakan perbedaan kepentingan kelompok yang ada dalam tubuh Masyumi (Zahro, 2004: 57). Namun NU pada akhirnya menjadi partai politik dalam Pemilu 1955, dengan memperoleh suara yang cukup signifikan. Selanjutnya, pada tahun 1973 NU menghendaki adanya fusi partai politik dan pada akhirnya menyatakan kembali kepada khittah 1926 pada tahun 1984 (Zahro, 2004: 63). Setelah itu, praktis NU menjadi sebuah lembaga yang berada di luar dari kegiatan politik praktis secara formal. Di lain pihak, NU masih belum sepenuhnya utuh keluar dari kontestasi politik formal, NU dinilai memiliki keterikatan dengan PKB yang pada akhirnya memunculkan nama Presiden Abdurrahman Wahid di awal masa reformasi. Pada masa reformasi ketidakterikatan NU pada wilayah politik formal masih mengalami perdebatan. Hal ini dikuatkan dengan keterikatan Abah Anton sebagai bendahara PCNU Kota Malang dengan PKB, bahkan di Kota Malang digunakan sebagai marketing politik oleh Abah Anton dan Sutiaji (Saputra, 2014: 204). Inilah yang pada akhirnya membuat fenomena gerakan sosial NU semakin menarik untuk dikaji

Penelitian ini bertempat di PCNU Kota Malang karena dianggap menjadi representasi dari gerakan NU secara nasional dengan kondisi jama'ah nahdliyin di Kota Malang yang besar. ${ }^{3}$ Selain itu, Aktor NU di Kota Malang menyebar di segala lini sepanjang tahun 2010-2015. Salah satunya pada dunia pendidikan tinggi. Setidaknya 4 Rektor Perguruan Tinggi Negeri di Kota Malang yang merupakan kader aktif PCNU Kota Malang, mereka adalah: Prof. M. Bisri, Rektor Universitas Brawijaya; Prof Mudjia Rahardjo, Rektor Universitas Islam Negeri Maliki; Dr. Tundung Subali, Rektor Politeknik Negeri Malang; Prof. Rofiudin, Rektor Universitas Negeri Malang ("Empat Rektor juga Mustasyar NU," 2015). Hal ini tentunya akan menjadi dinamika tersendiri bagi PCNU Kota Malang dan yang membedakannya dengan PCNU di Kab/Kota lain. Dengan nuansa pendidikan, kaderisasi NU di Kota Malang akan melibatkan para intelektual muda yang memiliki pemikiran dan ide mengenai gerakan NU. Salah satu contoh kader NU Kota Malang yang sukses menjadi pemimpin nasional ialah KH. Hasyim Muzadi. Oleh sebab itu, dengan melalui pertimbangan pada konteks dinamika gerakannya PCNU Kota Malang diambil sebagai tempat dari penelitian ini. Harapannya penelitian ini dapat mengetahui kiprah gerakan sosial PCNU Kota Malang sebagai organisasi sosial keagamaan melalui gerakan sosialnya pada tahun 2010-2015. Maka dengan ini penelitian ini berjudul: Gerakan Sosial Nahdlatul Ulama Tahun 2010-2015 (studi di Pengurus Cabang Nahdlatul Ulama' Kota Malang)

\section{Gerakan Sosial sebagai Perangkat Analisis}

Teori gerakan sosial pada dasarnya memiliki banyak varian mulai dari teori gerakan sosial klasik hingga gerakan sosial baru, namun dalam penelitian kali ini teori gerakan sosial dengan penggunaan variabel political opportunities, mobilizing structures dan cultural framings dianggap memiliki relevansi dengan permasalahan yang telah dirumuskan dalam rumusan masalah. Penggunaan ketiga variabel tersebut banyak didominasi oleh McAdam, McCarthy, \& Zald (1996), setelah melalui karya tulis gabungannya yang berjudul Comparative Persepectives on Social Movements. 
Sebagaimana diketahui, teori ini telah mengalami proses panjang dengan kajian analisis yang komperhensif antar satu peneliti dengan peneliti lainnya. Alhasil, definisi gerakan sosial selalu dapat berubah-ubah sesuai dengan bingkai penelitian. Namun, setidaknya dari beberapa argumentasi definitif beberapa definisi dapat digunakan sebagai rujukan dalam menyusun gambaran gerakan sosial.

McCharty dan Zald mendefiniskan bahwa: "gerakan sosial merupakan upaya terorganisasi untuk melakukan perubahan di dalam distribusi dalam hal apa pun yang bernilai sosial" (Fauzi, 2012: 4). Sedangkan Tilly menyebutkan gerakan sosial merupakan upaya-upaya mengadakan perubahan lewat interaksi yang mengandung perseteruan dan berkelanjutan di antara warga negara (Fauzi, 2012: 4). Melalui dua argumentasi tersebut didapatkan satu garis mengenai gerakan sosial sebagai suatu upaya perubahan yang terorganisasir, akan tetapi Tilly lebih menekankan dalam definisinya bahwa setiap gerakan sosial yang mengandung perubahan merupakan proses interaksi yang di dalamnya terdapat perseturuan yang berkelanjutan. Setelah melakukan mendalami beberapa argumentasi terkait definisi gerakan sosial, peneliti lebih condong untuk menggunakan definisi dari Sidney Tarrow yang melihat gerakan sosial sebagai: "collective challenges, based on common purposes and social solidarities, in sustained interactin with elits, opponents, and authorities" (Tarrow, 2011: 9). Dalam hal ini Tarrow lebih terperinci dalam mengutarakan definisinya ketimbang para pemikir lainnya, ia menekankan bahwa gerakan sosial meruapakan suatu tantangan kolektif yang diajukan oleh kelompok dengan tujuan yang sama dalam konteks interaksi yang berkelanjutan dengan elit, penguasa dan lawan. Bagi penelitian ini definisi tersebut akan menjadi patokan yang menjelaskan fenomena gerakan sosial NU. Bahwa gerakan sosial NU merupakan buah hasil dari perilaku dan tantangan kolektif oleh sekelompok masyarakat yang memiliki tujuan sama dalam proses interaksinya terhadap penguasa atau pemerintah atau terhadap lawan.

Sebagaimana dalam buku McAdam dkk, teori gerakan sosial dibagi dalam tiga variabel. Adapun variabel ini berfungsi sebagai poin analisis utama dari gerakan sosial yang telah dilakukan oleh obyek kajian. Nantinya, di dalam variabel juga terdapat indikator-indikator yang menopang dari variabel teori. Mereka menyebutkan bahwa:

"...the same three board sets of factors in analyzing the emergence and development of social movements. these three factors are: Firtsly. the structure of political opportunities and constraints confronting the movement. Secondly, the formas of organization (informal as well as formal), available to insurgents. Thirdly, the collective processes of interpretation, attribution and social construction that mediate between opportunity and action." (McAdam, dkk., 1996: 2)

Dalam pernyataan tersebut dijelaskan bahwasanya terdapat tiga variabel yang menentukan berkembangnya gerakan sosial, yaitu struktur kesempatan politik beserta dengan kendala yang dihadapi oleh gerakan. Berikutnya adalah bentuk daripada organisasi baik formal maupun informal. Terakhir ialah proses kolektif yang mampu memberikan signifikansi pada konstruksi sosial dan merupakan jembatan dari kesempatan politik dan aksi. Ketiga hal tersebut dapat dirangkum menjadi: kesempatan politik (political opportunities), struktur mobilisasi (mobilization structures) dan pembingkaian budaya (cultural framing). 
Adapun untuk memenuhi kerangka analisis di atas, penulis menggunakan metode penelitian kualitatif deskriptif dalam menjalankan riset ini. PCNU Kota Malang yang memiliki beragam problematika secara gerakan akan mampu ditelaah dengan baik apabila dijelaskan secara mendalam dengan pembahasan berupa data dan fakta berupa ucapan dan tulisan serta pola perilaku yang diamati. Moleong menyebutkan bahwa penelitian deskriptif merupakan penelitan yang menggunakan latar alamiah yang bermaksud untuk menafsirkan fenomena yang terjadi dan dilakukan dengan jalan melibatkan berbagai metode yang ada (Moleong, 2007: 5). Herdiansyah menyebutkan penelitian kualitatif akan mengarah kepada suatu kajian yang mengeksplorasi topik penelitian secara mendalam, detail terperinci serta menajdikan peneliti sebagai active leaner yang menceritakan fenomena yang dialami murni dari sudut pandang subyek (Hardiansyah, 2011: 1617). Adapun dalam penelitian ini sumber data primer yang digunakan meliputi: wawancara dan observasi. Sedangkan data primer meliputi: dokumentasi yang diperoleh dari Jurnal dan Buku atau dokumen-dokumen NU.

\section{Tiga Variabel Gerakan Sosial PCNU Kota Malang}

Pembahasan gerakan sosial PCNU Kota Malang merupakan analisis dari proses penelitian di lapangan. Tinjauan analisis akan disesuaikan dengan tiga variabel utama teori gerakan sosial karya Mc Adam, Mc Charty dan Zald, yakni: political opportunites, mobilization structure dan cultural framing. Gerakan sosial PCNU Kota Malang selama ini diketahui telah mengalami perkembangan antar waktu disebabkan dinamika dalam organisasi dan pengaruh eksternal berupa struktur politik.

\section{Kesempatan Politik}

Kesempatan politik (political opportinities) menjelaskan tentang analisis kemunculan atau dari gerakan sosial. Kemunculan gerakan sosial akan disebabkan lebih banyak dari aspek kesempatan politik. Artinya, dalam setiap perubahan politik dan konfliknya, secara otomatis memunculkan respon dari masyarakat sipil atau masyakarat yang berkempentingan untuk melakukan gerakan. PCNU Kota Malang diketahui sampai saat ini masih tetap eksis melakukan gerakan sosial dikarenakan tidak lepas dari tiga hal. Pertama: Kondisi struktur politik. Demokrasi lokal yang ditetapkan pada masa reformasi menyebabkan proses partisipasi politik meningkat, salah satunya partisipasi dalam bentuk gerakan sosial. Hal ini benar-benar dimanfaatkan oleh PCNU Kota Malang untuk melakukan partisipasi dalam bentuk gerakan sosial. Gus Is menyebutkan bahwa demokrasi menjamin partisipasi politik, yang secara otomatis NU diuntukngkan karena diberi keleluasaan untuk melakukan kegiatan keorganisasian (Israqun Najah, wawancara penulis, 9 Maret 2015).

Keterbukaan akses kelembagaan yang memberikan ruang aktualisasi gerakan PCNU Kota Malang memiliki akses lebih lebar setelah terpilihnya Abah Anton dan Sutiaji sebagai Walikota dan Wakil Walikota (Israqun Najah, wawancara penulis, 9 Maret 2015). Sangadji (wawancara penulis, 20 Agustus 2015) yang merupakan Sekertaris Pimpinan Daerah Muhammadiyah (PDM) Kota Malang juga mengutarakan jika terpilihnya Abah Anton memberikan akses kepada PCNU Kota Malang dan PDM Kota Malang untuk berdiskusi masalah sosial kebijakan, seperti penertiban sex bebas. Keterbukaan ini lantas memunculkan rutinitas gerakan sosial melalui proses konsolidasi antara NU 
dan Pemerintah. Israqun Najah (wawancara penulis, 9 Maret 2015), yang biasa dipanggil Gus Is menyatakan bahwa dengan terpilihnya Abah Anton memudahkan koneksivitas antara masyarakat NU dengan Pemerintah. Pernyataan Gus Is juga ditegaskan oleh Yuwanda (wawancara penulis, 6 Agustus 2015) selaku Wakil Sekertaris PCNU Kota Malang yang menuturkan mediasi saat ini lebih sering dilakukan setelah terpilihnya Abah Anton.

Salah satu bukti nyata dilapangan ialah dengan penguatan atau penegakan perda Miras. Dinyatakan oleh KH. Chamzawi (wawancara penulis, 17 Maret 2015) bahwa saat ini PCNU Kota Malang berupaya untuk memberikan masukan pemerintah untuk memberantas peredaran Minuman Keras di Kota Malang melalui penegakan Peraturan Daerah. Dengan upaya komunikasi yang intensif oleh PCNU Kota Malang, pada akhirnya beberapa kurun waktu terakhir Pemerintah Kota melalui jajaran penegak hukum mulai memberantas peredaran miras ("Pemkot Malang Musnahkan 5.110 Botol Miras," 2015). Artinya, dengan terbukanya celah akses terhadap struktur di Pemerintah Kota Malang membuktikkan bahwa gerakan NU mengalami peningkatan orientasi hasil dan dimungkinkan untuk terus muncul secara berkelanjutan dengan ditunjang oleh akses terhadap pemerintahan.

Kedua, Gerakan sosial merupakan instrumen dari struktur politik sebagai daya penyeimbang untuk menyeimbangkan ketimpangan yang terjadi. Organisasi gerakan sosial dapat menyeimbangkan, karena gerakan sosial mampu memberikan kontribusi yang sulit dilakukan oleh pemerintah atau bahkan tidak bisa dilakukan, misalnya pemberdayaan masyarakat secara keberlanjutan dengan mengedepan nilai-nilai yang substansial. Proses ini hanya dapat dilakukan oleh organisasi gerakan, lantaran organisasi gerakan memiliki kesukarelawanan (voulantarism) dari para sumber dayanya. Di Kota Malang keseimbangan politik belum bisa dikatakan berada titik ideal. Terbukti salah satunya dengan melihat dengan jumlah kemiskinan yang masih tinggi ("Angka Kemiskinan Kota Malang Masih Tinggi," 2015). Ditambah lagi menurut Yuwanda (wawancara penulis, 6 Agustus 2015), Kota Malang sejak tahun 2010 belum mampu memberikan melakukan upaya pengentasan kemiskinan dan keterbelakangan pendidikan dengan baik. Hal ini disebabkan kurangnya anggaran dan kepemimpinan yang baik.

Struktur politik yang belum seimbang juga ditegaskan oleh Mujtabah. Mujtabah (wawancara penulis, 25 Mei 2015) mengatakan selama ini Kota Malang belum dinilai berhasil dalam kinerja pemerintahannya dalam segi basis kebijakan untuk pemenuhan basis kebutuhan masyarakat yakni, ekonomi, kesehatan, dan pangan. Hal demikian kemudian diperparah dengan angka dugaan korupsi sebagai patologi yang masih menguat. MCW menyebutkan, beberapa dugaan korupsi di Kota Malang diantaranya masalah pembangunan pasar, instalasi air minum PDAM, korupsi perjalanan dinas DPRD Kota Malang, pemanfaatan sumber daya alam, dana hibah, dan asuransi DPRD ("LSM Malang Laporkan Korupsi Rp 163 Miliar ke KPK," 2014). Maka dari itu, data-data ini menyebutkan struktur pemerintahan politik di Kota Malang masih belum mampu memberi dampak kesejahteraan yang signifikan, justru angka patologi birokrasi seperti korupsi terus meningkat. Winartono (wawancara penulis, 7 Agustus 2015) juga menyebutkan ketidakseimbangan struktur politik di Kota Malang juga berkembang beriringan dengan potensi konflik yang terjadi. Maka dari itu, PCNU Kota Malang sebagai organisasi gerakan sosial keagamaan muncul dengan inisiatif menyeimbangkan kondisi struktur politik. 
Muhammad Nafi' (wawancara penulis, 17 Maret 2015) atau biasa disapa Gus Nafi' mengemukakan bahwa untuk menunjang keseimbangan suatu negara, NU berposisi sebagai media kerakyatan dan keumatan, bahwa hubungan NU dengan negara itu substansialisme inklusif bukan formalisme eksklusif." Penjelasannya, yaitu NU lebih menekankan bahwa jika negara menjalankan nilai-nilai keislaman merupakan suatu hal yang cukup, meskipun simbol keagamaan Islam tidak dipakai.

Ketiga, Jaringan aktor di PCNU Kota Malang bisa dikatakan sebagai rangkaian yang komplit. Dibuktikan oleh jaringan aktor perubahan dan elit politik yang terkombinasi yakni: kyai, aktivis, akademisi, politisi, jurnalis. ${ }^{4}$ Keduanya memiliki sumber daya kultural NU yang sewaktu-waktu memainkan aktor perubahan bersama-sama dengan sumber daya lainnya. Dalam jejaring pemilik media, di Kota Malang NU juga memiliki jaringan kultural, sebut saja tokoh-tokoh dalam dewan redaksi Malang Pos seperti Mahmudi yang merupakan Sekertaris PCNU Kota Malang, dan Kurniawan Muhammad Redaktur Radar Malang yang notabenya bisa dikatakan orang NU setelah pernah menjadi aktivis di PMII. Jaringan yang begitu kompleks ini idealnya mampu memberikan signifikansi pada kemunculan gerakan PCNU Kota Malang.

\section{Struktur Mobilisasi}

Sumber daya PCNU Kota Malang terbagi, namun tidak terpisah, yakni sumber daya kultural dan struktural. Sumber daya kultural merupakan kader PCNU Kota Malang yang tidak terverifikasi data sebagai pengurus organisasi dan tidak memiliki Kartu Tanda Anggota (KartaNU), akan tetapi memiliki pemahaman ideologi sesuai dengan nilai-nilai NU. Selama ini kekuatan sumber daya kultural menjadi basis gerakan $\mathrm{NU}$. Hal ini dinyatakan $\mathrm{Hj}$. Muthammimah Hasyim ( $\mathrm{Hj}$. Muthammimah Hasyim, wawancara penulis, 7 Agustus 2015) selaku Ketua Muslimat NU Kota Malangyang, atau lebih akrab disapa Nyai Hasyim menyatakan bahwa kekuatan muslimat NU dan PCNU Kota Malang terletak pada kultur. Gerakan kultur sebagai basis, sebenarnya dikarenakan dari pola keorganisasian PCNU Kota Malang yang lebih mengedepankan pada proses aktualisasi nilai-nilai tradisi masyarakat..

Pada proses kaderisasi dan keanggotaannya, NU merupakan organisasi terbesar seluruh Indonesia, termasuk di Kota Malang. Kurang lebih sebanyak 55 pondok pesantren dengan latar belakang NU dan 89 lembaga pendidikan Ma'arif yang berfungsi sebagai pilar utama dari kaderisasi PCNU Kota Malang ("Malang Dalam Angka 2011," 2011). Tersebarnya pilar ini merupakan salah satu kekuatan dari NU dalam melakukan rekrutmen kaderisasi person to person sejak usia dini. $\mathrm{Hal}$ ini kemudian ditunjang dari organisasi kepemudaan sebagai basis kaderisasi, seperti: IPNU Ikatan Pelajar Nahdlatul Ulama' (bagi yang putera) dan Ikatan Pelajar Putri Nahdlatul Ulama IPPNU (bagi yang puteri), PMII (Pergerakan Mahasiswa Islam Indonesia). Setidaknya dari proses formal PCNU Kota Malang memiliki anggota setiap ranting sekitar 30 kader (Yuwanda, wawancara penulis, 6 Agustus 2015). Belum lagi ditambahkan kader yang terdaftar melalui pengurus Muslimat. Disebutkan setidaknya lebih dari 12.000 anggota muslimat terdaftar dalam buku keanggotaan Muslimat NU Kota Malang ( $\mathrm{Hj}$. Muthammimah Hasyim, wawancara penulis, 7 Agustus 2015). Dengan jumlah kekuatan basis masa tersebut setidaknya proses kaderisasi gerakan PCNU Kota Malang merupakan kaderisasi terbaik dibanding gerakan sosial keagamaan sejenis di Kota Malang. 
Untuk menunjang jumlah kuantitas yang besar, PCNU Kota Malang mengupayakan pola komunikasi antar sumber daya. Salah satu agenda untuk mengupayakan terjalinnya komunikasi yang baik adalah melalui pertemuan rutin setidaknya sebulan sekali untuk kooordinasi gerakan, serta untuk komunikasi dilakukan melalui media IT (Yuwanda, wawancara penulis, 6 Agustus 2015). Upaya koordinasi ini memiliki tradisi yang telah membudaya dalam setiap kepengurusan organisasi. Tidak cukup Yuwanda saja yang menyebutkan bahwa ada koordinasi setiap bulan, Nyai Hasyim juga mengutarakan bila ada pertemuan pimpinan Muslimat NU Kota Malang setidaknya tiga bulan sekali dengan mengumpulkan 165 ranting dalam satu forum (wawancara penulis, 7 Agustus 2015).

Dalam menjalankan upayanya, PCNU Kota Malang mengedepankan setidaknya tiga proses aktualisasi gerakan yakni: Pertama, Program Struktural. Sebagai organisasi resmi PCNU Kota Malang memiliki berbagai program kerja yang diwujudkan sebagai sarana untuk melakukan pemberdayaan sosial. Konsep program kerja banyak dibahas dalam setiap Muskercab atau dalam agenda rapat resmi organisasi. Dalam penerapannya dilaksanakan oleh pelaksana teknis. Misalnya, advokasi hukum yang dilaksanakan oleh lembaga bantuan hukum. Juga dengan usaha-usaha pengembangan koperasi dan ekonomi mikro yang tertuang dalam program kerja dari lembaga ekonomi. Secara garis besar, konsep dalam program kerja dirujuk dari landasan organisasi atau AD/ART dan menyesuaikan kondisi siosial keagamaan yang terjadi.

Kedua, Mediasi. Usaha lainnya dalam melakukan aktualisasi fungsi gerakan sosial yang dilakukan oleh PCNU Kota Malang adalah melalui proses mediasi dan kerjasama dengan pihak pemerintah atau lembaga yang lain. Proses ini dinilai memiliki signifikansi karena memiliki dampak yang cukup baik. Beberapa kebijakan dari Abah Anton diantaranya merupakan bagian dari proses mediasi antara NU dan pemerintah. Misalnya, saat ini diberikan santunan kepada guru ngaji TPQ dan madrasah diniyah, mudin, dan ta'mir masjid (Mujtabah, wawancara penulis, 25 Mei 2015). Proses pemberian ini dilakukan setelah pengurus NU menyadari bahwa banyak guru dan ta'mir masjid yang masih belum sejahtera secara perekonomian. Pemberian santunan ini dilakukan melalui program Pemerintah Daerah (Israqun Najah, wawancara penulis, 9 Maret 2015). Harapannya melalui mediasi ini masyarakat yang mengabdikan diri sebagai tokoh agama dalam ruang sosial dapat melakukan aktualisasi secara berlanjut dengan dijamin kesejahteraannya oleh pemerintah. Sebelumnya beberapa guru ngaji yang resah dikarenakan tidak mendapatkan perhatian pemerintah justru mulai banyak memilih profesi baru dikarenakan situasi ekonomi keluarga yang semakin sulit.

Ketiga, Dakwah. Upaya berikutnya yang dilakukan adalah melalui proses dakwah. Dakwah merupakan kegiatan pengajian berupa tausiah, istighosah/tahlil, ceramah, khotbah dsb. Melalui kegiatan penanaman nilai-nilai religiusitas yang ditanamkan. Proses dakwah oleh PCNU Kota Malang dilakukan oleh banyak kanal gerakannya. Misalnya melalui Muslimat yang selalu memberikan ceramah agamadalam setiap pertemuannya ( $\mathrm{Hj}$. Muthammimah Hasyim, wawancara penulis, 7 Agustus 2015). Begitupun dengan Lapkesdam yang memberikan dakwah pencerahan mengenai toleransi antar umat beragama secara berkelanjutan (Winartono, wawancara penulis, 7 Agustus 2015). Sedangkan, Aswaja Center memberikan pemahaman berupa Islam Aswaja yang mampu dikontekstualisasikan pada kehidupan masyarkat (Yuwanda, wawancara penulis, 6 Agustus 2015). 
Beberapa lembaga, lajnah dan Banom di PCNU Kota Malang masing-masing juga melakukan hal serupa.

\section{Pembingkaian Budaya}

Adapun paradigma gerakan sosial PCNU Kota Malang tidak bisa dilepaskan dari landasan berpolitik aliran Sunni (Aswaja). ${ }^{5} \mathrm{Hal}$ ini ditegaskan dalam penelitian M. Ali Haidar dan M Ridwan mengenai paradigma atau landasan berpolitik NU. Aliran politik Sunni pada dasarnya berorientasi pada politik yang akomodatif dan kompromistis (Ridwan, 2004: 11). PCNU Kota Malang merupakan organisasi gerakan sosial yang bukan tergerak melalui isu spesifik, melainkan PCNU Kota Malang sebagai organisasi gerakan bergerak pada wilayah persoalan penanaman nilai-nilai keagamaan. Akan tetapi, PCNU Kota Malang tetap memiliki komitmen untuk menyerap persoalan/isu sosial politik yang terjadi di area gerakan. Komitmen ini ditujukan sebagai upaya memberikan perlindungan sosial bagi masyarakat atas segala permasalahan yang terjadi. lalah Lailatul ljtima' yaitu sebagai proses penjaringan aspirasi masyarakat yang dilakukan PCNU Kota Malang dari tingkat bawah sampai atas.

Proses penjaringan tersebut dimulai dari proses pengajian rutin yang juga membahas persoalan sosial setiap hari kamis malam di masing-masing rantig. Pembahasan melalui musyawarah dilakukan pada tahap ini untuk mengidentifikasi persoalan yang bisa diselesaikan sendiri atau diangkat ke MWC NU. Permasalahan yang bisa diselesaikan sendiri, maka dibahas secara musyawarah pada forum tersebut. Sedangkan masalah di MWC NU akan dikumpulkan dengan masalah yang lainnya, lalu akan di hubungkan ke PCNU. PCNU kemudian memprioritaskan persoalan yang terjadi sesuai dengan landasan organsiasi. Setelah itu pada tahap akhirnya PCNU mengeksekusi persoalan dengan melakukan mediasi melalui pemerintah atau pihak yang terkait. Proses ini cukup efektif untuk menangkap permasalahan dan wacana baru terjadi dimasyarakat (Yuwanda, wawancara penulis, 6 Agustus 2015). Nyai Hasyim (wawancara penulis, 7 Agustus 2015) bahkan sampai mengatakan salah satu kunci sukses gerakan sosial di PCNU Kota Malang ialah melalui lailatul ijtima' ini. Maka dari itu, PCNU Kota Malang meskipun bukan organsiasi yang berbasis pada isu khusus, tetap selalu mengerti permasalahan yang terbaru di masyarkat melalui proses jaring aspirasi yang dilakukan.

\section{Kritik Gerakan Sosial PCNU Kota Malang}

Dengan mengambil dasar fakta dari narasumber pembanding dan ungkapan kritik yang dilontarkannya, maka peneliti memiliki tiga poin yang dilontarkan sebagai kritik terhadap gerakan sosial PCNU Kota Malang: Pertama: Pola gerakan PCNU Kota Malang masih menjadikan Pemerintah sebagai intrumen penting pengambil kebijakan yang mampu merubah kondisi sosial. Husunun $\mathrm{N}$ Djuraid (wawancara penulis, 11 Agustus 2015) selaku komisaris Malang Post menyatakan kritik kepada gerakan PCNU Kota Malang yang masih berharap lebih pada sarana politik sebagai media perubahan sosial. Hal ini juga ditegaskan oleh Sangadji (wawancara penulis, 20 Agustus 2015) bahwa selama ini teridentifikasi kecenderungan PCNU Kota Malang yang menjadikan sarana politik 
praktis sebagai instrumen untuk melakukan gerakan sosial. Akibatnya, hal ini menjadi kontradiktif dengan komitmen Khittah 1926 NU.

Kedua, Gerakan sosial PCNU Kota Malang dirasa belum mampu memberikan variasi gerakan. $\mathrm{Hal}$ ini dibuktikan dengan media-media yang digunakan masih belum optimal. Seperti halnya website PCNU sendiri masih belum aktif sejak tahun 2013. Selain itu, proses kegiatan yang mengedepankan pada upaya penyadaran masyarakat melalui media-media dialektis dan kritis masih sangat jarang dilakukan. Lailatul ljtima' yang selama ini dilakukan untuk mewadahi aspirasi warga NU Kota Malang seringkali kalah oleh dominasi kyai seperti yang dinyatakan oleh Winartono (wawancara penulis, 7 Agustus 2015). Hal ini menyebabkan tidak mampu berubahnya struktur sosial politik yang terus menindas terhadap masyarakat kecil.

Ketiga, jaringan aktor dan kualitas kader yang dimiliki oleh PCNU Kota Malang telah diakui merupakan salah satu sumber daya struktur NU yang baik oleh PBNU (Adnan Anwar, wawancara penulis, 26 Februari 2015). Namun, sayangnya beberapa jaringan aktor yang tergerak dalam struktur ataupun di luar struktur belum memberikan suatu simpul dalam komitmen bersama untuk memperjuangkan nilai-nilai pembebasan dalam Islam. Pada akhirnya kaderisasi ini hanya mampu meninggikan posisi tawar NU dengan organisasi kegamaan Islam lainnya. Menurut Winartono (wawancara penulis, 7 Agustus 2015) banyaknya aktor perubahan di PCNU Kota Malang menyebabkan konsekuensi persoalan perbedaan pemikiran muncul antar aktor. Hal ini kemudian ditunjang oleh pernyataan Husnun (wawancara penulis, 11 Agustus 2015) yang menitikberatkan persoalan manajerial PCNU Kota Malang belum mampu terlihat baik. Seharusnya organisasi sebesar NU perlu ditunjang oleh kualitas manajerial dan kepemimpinan yang baik. Sehingga pemimpin yang memiliki kekuatan manajerial dan kepemimpinan yang baik dapat meredam perbedaan kepentingan dalam organisasi.

\section{Kesimpulan}

PCNU Kota Malang merupakan organisasi sosial keagamaan yang kemunculan gerakannya pada tahun 2010-2015 ditunjang dengan sistem demokrasi yang menjamin adanya partisipasi politik di Kota Malang. Potensi gerakan sosial PCNU Kota Malang selanjutnya ditunjang dengan aktor perubahan yang dimiliki yakni: kyai, akademisi, aktivis dan politisi. Dalam aksi gerakan sosialnya PCNU Kota Malang mengedepankan proses gerakan melalui mediasi, dakwah dan program struktural. Dalam gerakan sosialnya, PCNU Kota Malang masih menggunakan pandangan kyai sebagai yang utama dan mengedepankan amanah Muktamar 2010 yakni: pendidikan, kesehatan dan ekonomi.

PCNU Kota Malang menggunakan Lailatul ljtima' sebagai proses bertemunya antar kader ditingkat ranting untuk mendiskusikan permasalahan sosial di sekitarnya. PCNU Kota Malang menggunakan analisis setiap permasalahan dengan menggunakan paradigma gerakan sosial sunni. Secara kritis, PCNU Kota Malang belum mampu memberikan suatu gerakan yang memiliki dampak terhadap perubahan sosial yang signifikan terhadap transformasi sosial. Dikarenakan upaya-upaya yang dilakukan belum mampu signifikan memberikan penyadaran terhadap masyarakat dan tidak mampu menerobos struktur kekuasaan dominan yang ada. 
Dari kesimpulan di atas, ada beberapa saran yang penulis ingin sampaikan. Pertama, PCNU Kota Malang harus memberikan perhatian khusus pada pembaharuan strategi gerakan sosial. Kedua, mdernisasi organisasi harus dilakukan oleh PCNU Kota Malang dengan mengupayakan penataan terhadap anggota dan rekrutmen. Ketiga, khittah 1926 harus diberikan indikator yang jelas oleh PCNU Kota Malang, sehingga kedepannya garis halauan dalam berpolitik NU menjadi batasan yang jelas. Hal ini tentunya akan pula mengantisipasi posisi NU sebagai status quo dari kekuasaan. []

\section{Ucapan Terima Kasih}

Penulis haturkan terima kasih kepada PCNU Kota Malang yang telah memberikan akses selama peneliti melakukan riset. Selain itu, peneliti juga mengucapkan terima kasih kepada bapak ibu dosen Program Studi llmu Pemerintahan yang telah memberikan masukan dan bimbingan selama peneliti melakukan proses penelitian. Secara khusus peneliti juga menghaturkan terima kasih kepada Gus Is, KH. Chamzawi, Gus Adnan Anwar, Ustadz Hilman, Ustadz Nafi, Mas Winartono, Hj, Mutamimmah Muzadi, Mas Tabah, Pak Mahmudi, Pak Husnun, dan Pak Yuwanda yang telah bersedia menjadi narasumber peneliti.

\section{Pendanaan}

Penulis tidak menerima bantuan pembiayaan untuk penelitian, kepenulisan (authorship), dan publikasi dari pihak manapun.

\section{Catatan}

1 Lawan dalam pengertian ini diartikan sebagai struktur kekuasaan politik yang bertentangan dengan tujuan organisasi gerakan sosial

2 NU didirkan sebagai organisasi keagamaan islam atau dalam istilahnya jam'iyyah diniyyah ljtima'iyah Islamiyyah

3 Hal ini dibuktikan dengan pernyataan yang diucapkan dalam narasumber. Selain itu, dibuktikan pula dengan kenyataan terpilihnya Abah Anton sebagai Walikota yang merupakan kader NU dan dipilih dengan mayoritas pemilih berlatar belakang NU.

4 Ini dibuktikan dari sebaran narasumber yang dijaring penulis, yakni di kalangan akademisi ada 4 rektor perguruan tinggi, di kalangan LSM ada Gus Durian dan Averroes, di kalangan politisi ada Abah Anton dan Sutiaji, di kalangan kyai ada KH Chamzawi dan Marzuki Musta'mar. Namanama tersebut merupakan contoh dari bagian persebaran aktor. Sedangkan untuk jurnalis ada di Malang Pos dan Radar Malang

5 Penulis menyamakan paradigma gerakan sosial PCNU Kota Malang dengan paradigma NU secara general dikarenakan kesamaan pandangan dan landasan gerakan 


\section{Daftar Pustaka}

Angka Kemiskinan Kota Malang Masih Tinggi. (2015). Diakses pada 30 Januari 2015, dari http:// www.malang-post.com/kota-malang/82519-angka-kemiskinan-kota-malang-masih-tinggi

Empat Rektor juga Mustasyar NU. (2015). Diakses pada 30 Januari 2015, dari https://www. malangtimes.com/berita/14112014/16072/empat-rektor-juga-mustasyar-nu.html.

Fauzi, I. A. (2012). Sintesis Saling Menguntungkan: Hilangnya "Orang Luar" dan "Orang Dalam." In Q. Wiktorowicz (Ed.), Aktivisme Islam Pendekatan Teori Gerakan Sosial (pp. 1-26). Jakarta: Democracy Project.

Hardiansyah, H. (2011). Metodologi Penelitian Kualitatif untuk IImu-Ilmu Sosial. Jakarta: Salemba Humanika.

LSM Malang Laporkan Korupsi Rp 163 Miliar ke KPK. (2014). Diakses pada 25 Juni 2015, dari https://nasional.tempo.co/read/614371/lsm-malang-laporkan-korupsi-rp-163-miliar-ke-kpk

Malang Dalam Angka 2011. (2011). Badan Pusat Statistik Kota Malang.

McAdam, D., McCarthy, J. D., \& Zald, M. N. (Eds.). (1996). Comparative Perspectives on Social Movements Political Opportunities, Mobilizing Structures, and Cultural Framings. Cambridge: Cambridge University Press.

Moleong, L. J. (2007). Metodologi Penelitian Kualitatif. Bandung: PT. Remaja Rosdakarya.

Pemkot Malang Musnahkan 5.110 Botol Miras. (2015). Diakses pada 25 Februari 2015, dari https://www.republika.co.id/berita/nasional/daerah/15/03/09/nkxkkz-pemkot-malangmusnahkan-5110-botol-miras

Ridwan. (2004). Paradigma Politik NU Relasi Sunni-NU dalam Pemikiran Politik. Yogyakarta: Pustaka Pelajar.

Saputra, M. I. (2014). Marketing Politik Pasangan Kepala Daerah dalam Pemilukada Kota Malang (Studi Kasus Tim Sukses Pemenangan Pasangan Abah Anton Dan Sutiaji dalam Pemilukada Kota Malang 2013). Jurnal Administrasi Publik, 2(2), 250-256. Diakses dari http://administrasipublik. studentjournal.ub.ac.id/index.php/jap/article/view/366

Tarrow, S. G. (2011). Power in Movement: Social Movements and Contentious Politics Updated and Revised 3rd Edition. Cambridge University Press. New York.

Zahro, A. (2004). Tradisi Intelektual NU Lajnah Bahtsul Masail 1926-1999. Yogyakarta: LKiS.

\section{Daftar Informan}

Adnan Anwar, Wakil Sekjen PBNU, 26 Februari 2015, pukul 14.00 WIB.

Hj. Muthammimah Hasyim, Ketua Muslimat NU, 7 Agustus 2015, pukul: 9.30 WIB.

Husnun N Djurad, Komisaris Malang Post, 11 Agustus 2015, pukul 15.30 WIB.

Israqun Najah, Ketua Umum PCNU Kota Malang, 9 Maret 2015, pukul 13.00 WIB.

KH Chamzawi, Rais Syuriah PCNU Kota Malang, 17 Maret 2015, pukul 13.05 WIB.

Muhammad Nafi', Wakil Syuriah am PCNU Kota Malang, 17 Maret 2015, pukul 14.00 WIB. 
Mujtabah, Staf DRD Kota Malang, 25 Mei 2015, pukul 21.00 WIB.

Sangadji, Sekertaris PDM Kota Malang ,20 Agustus 2015, pukul 18.00 WIB.

Winartono, Ketua Bidang Kajian dan Pengembangan SDM Lapkesdam NU, 7 Agustus 2015, pukul 15.00 WIB.

Yuwanda, Wakil Sekertaris PCNU Kota Malang, Anggota Aswaja Center, 6 Agustus 2015, pukul 10.00 WIB.

\section{Tentang Penulis}

Muhammad Luthfil Hakim adalah Mahasiswa Magister Administrasi Publik, Pascasarjana Fakultas IImu Administrasi, Universitas Brawijaya, sekaligus staf peneliti di Pusat Kajian Dinamika dan Sistem Pembangunan FEB Universitas Brawijaya. Area riset yang digeluti adalah kebijakan publik, studi pembangunan, dan politik agama. 